\title{
Are China’s Financial Reforms Leaving the Poor Behind?*
}

\author{
Loren Brandt \\ Department of Economics, University of Toronto, and William Davidson Institute, \\ University of Michigan \\ Albert Park \\ Department of Economics and William Davidson Institute, University of Michigan \\ Wang Sangui \\ Institute of Agricultural Economics, Chinese Academy of Agricultural Sciences
}

March 2003

*An earlier draft of this paper was prepared for the conference on "Financial Sector Reform in China,” JFK School of Government, Harvard University, September 11-13, 2001. 


\section{Are China's Financial Reforms Leaving the Poor Behind?}

\section{Introduction}

Since economic reforms began, the Chinese state has shifted the locus of control over the allocation of resources from the fiscal to the financial ledger (Sehrt, 1999). Under the planning system, funds were mobilized by setting prices to concentrate profits in state-owned industry (Naughton, 1995). During the reform period, market competition eroded the profitability of SOEs, and the government struggled to establish an effective taxation system to generate revenue (Wong, Heady, and Woo, 1995). However, by asserting its control over the banking system, the state was able to continue directing national resources to support its most important political constituencies, in particular urban workers in state-owned enterprises (Brandt and Zhu, 2000). This strategy was facilitated by the rapid growth of individual private savings in state-owned banks, which have come to dominate China's national savings (Kraay, 2000). ${ }^{1}$ Thus, during the reform period, the financial system increasingly became the key mechanism by which the government realized its distributional goals.

Government control over financial resource allocation can either increase or decrease inequities in credit access associated with differences in individual wealth or regional level of development. For example, as in many other developing countries, state policies in China, including lending by state-owned banks, have been biased against rural areas in favor of urban areas (Putterman, 1992; Nyberg and Rozelle, 1999). However, across provinces, there has been an inverse relationship between the degree of financial intermediation and the level of economic development, suggesting that richer, fastergrowing provinces have been implicitly taxed (Park and Sehrt, 2001). ${ }^{2}$ The lack of a free

\footnotetext{
${ }^{1}$ According to official data, most of the increase in deposits was by urban residents, although the urbanrural distinction is not always clear because rural residents may deposit funds in any bank. In 1998, the percentage of individual deposits from rural areas (defined as deposits in Rural Credit Cooperatives) was 20 percent, compared to 26 percent in 1990. Urban deposits in 1998 were 8.1 times that in 1990, rural deposits were 5.7 times as great. On a per capita basis, the deposits of urban residents in 1998 were nearly 10 times that of rural residents. Individual deposits accounted for 55 percent of all deposits in all financial institutions in 1999, with the second largest category being enterprise deposits (34 percent).

${ }^{2}$ Park and Sehrt (2001) find that the most significant factor affecting intermediation across provinces is the size and profitability of the state sector, so that these regional transfers may reflect transfers from the nonstate to the state sectors.
} 
interbank market may have prevented the outflow of funds from poorer regions, especially from Rural Credit Cooperatives (RCCs, or xinyongshe), which account for a large share of rural savings but do not have a hierarchical structure to facilitate interregional transfers. In poor areas, political goals to support local development also may have led bank officials to lend more than they might in a more commercialized system.

By the mid-1990s, policy-driven lending proved to be unsustainable. Slower overall growth and skyrocketing SOE losses in the 1990s, and the resulting deterioration in the financial performance of banks, led to aggressive new reform efforts to restructure enterprises and to reduce the stock of non-performing loans in state banks (Lardy, 1998). At a deeper level, the reforms recognized the high cost of pursuing distributional objectives at the expense of efficiency objectives. An excessive amount of nonperforming loans becomes unsustainable and eventually crowds out new lending, suggesting the desire for balance. Banking reforms included efforts to promote bank independence and commercialization by separating banks into policy and commercial banks, and by increasing the economic and political incentives to make loans based on profitability criteria rather than to support failing enterprises (Park and Sehrt, 2001).

These changes altered the way in which banks allocate scarce financial resources. One concern is that resource flows out of poor areas and into rich areas may increase as money chases higher returns and banks abandon lending in places where transaction costs are high and good projects are hard to find. Commercial financial institutions worldwide often exclude the poor because they lack collateral, engage in riskier projects, and demand small loans that are expensive to administer (Besley, 1994). In fact, there may be sound efficiency reasons for encouraging financial flows out of poor areas if the marginal returns to capital are higher elsewhere.

On the other hand, recent research has questioned the assumption that the poor are not credit-worthy or lack demand for loans. China's own flagship poverty alleviation program, which provides subsidized loans to poor regions, is premised on the conviction that such loans can be used productively. If the unprofitability of lending in poor areas in a more commercial policy environment is due to institutional inflexibility (e.g., strictly enforced interest ceilings) or weak governance structures, rather than the lack of good projects, there may be both efficiency and distributional grounds for concern if financial 
reform leads to greater funds flowing out of poor areas. Thus, distinguishing among the reasons for poor loan performance becomes a fundamental question in assessing the consequences of reform. Even if project returns were lower in poor areas, the government could choose to subsidize lending in such areas if expected social returns were sufficiently high (Morduch, 2000).

This paper examines the distributional consequences of financial reform and bank performance in China's rural areas. Specifically, we describe and analyze changes in the degree of financial intermediation by rural financial institutions in rich and poor areas during the mid-1990s when key financial reforms were being implemented. This is an important question because it addresses the key efficiency-equity tradeoff of market reform. It is now well-established that financial intermediation plays an important role in growth, so that current disparities in the allocations of financial resources can lead to growth differences that shape future patterns of inequality (Gertler and Rose, 1996; Levine, 1997; King and Levine, 1993; Levine and Zervos, 1998; and Rajan and Zingales, 1998). Given rapidly rising regional income inequality in China and the concern shared by many that credit access is a key constraint to development in China's poorest areas, better understanding of the distributional consequences of financial reform takes on added importance. This is especially true given the lack of any systematic empirical study of this issue.

In this paper, we study changes in financial intermediation and financial performance over time using a unique data set from surveys of rural financial institutions conducted by the authors in two rich, coastal provinces (Zhejiang and Jiangsu) and in two poor, interior provinces (Sichuan and Shanxi) in 1998 and 1999. Subsequent data collection from RCCs in Sichuan and Shanxi allow us to update some of our financial performance measures all the way to 2002. The paper focuses on the financial role played by the two main rural financial institutions in China, RCCs and branches of the Agricultural Bank of China (ABC, or nongye yinhang). Because of data limitations, we do not consider informal borrowing or lending and saving in other financial institutions. However, informal networks tend to be highly segmented, and informal organizations such as Rural Credit Foundations that reached a large scale in rural areas have been shut 
down. ${ }^{3}$ Thus, ABC branches and RCCs play a pivotal role in achieving effective financial intermediation in rural areas.

Focusing on rural financial institutions has several motivations. First, rural China remains home of 70 percent of China's population. Rural financial institutions are the primary source of formal credit for millions of farmers and self-employed workers in rural areas whose production and consumption activities create demand for credit services. Second, most of China's poor live in remote rural areas, so their access to credit is of particular importance in assessing the distributional impacts of financial reform. The international development community and the Chinese government have emphasized credit provision, through subsidized loans and microfinance programs, as a key part of China's poverty alleviation strategy (Park and Ren, 2001). Third, rural China also is the location of many of China's most dynamic industrial enterprises, including townshipowned, village-owned, and private enterprises. Rural enterprises accounted for 45 percent of Chinese exports in 1998 and because they are labor-intensive, in line with China's comparative advantage, their future success will be critical to China's ability to gain the benefits of WTO accession. Recently, many have expressed concern about the difficulty that non-state enterprises, especially private enterprises, face in obtaining formal credit (Nyberg and Rozelle, 1999; Brandt and Li, forthcoming). Finally, rural financial institutions account for a large share of total deposits and loans in China, but thus far much less is know about the lending performance and behavior of these institutions than the larger specialized banks that provide most of the loans to industrial state-owned enterprises.

The paper is organized as follows. In section 2, we describe the survey of rural financial institutions that is the main source of data for the study. China's rural financial institutions and financial reforms are introduced in section 3. The empirical analysis is presented in the next two sections. Section 4 describes changes in the extent of financial intermediation in areas with different income levels and in different provinces, and for

\footnotetext{
${ }^{3}$ Until 1999, rural cooperative foundations (RCFs, or nongcun hezuo jijinhui) could be found in many townships, especially in richer areas (38 percent of all townships in 1996). The RCFs were quasigovernment organizations under the administrative supervision of the Ministry Agriculture. In 1996, RCF deposits were estimated to be one ninth that of RCCs. A national survey found that 24 percent of RCF loans went to TVEs and 45 percent to households (Park, Brandt, and Giles, forthcoming). RCFs often had significant involvement of township officials, but lacked legal status as financial institutions. Following a 1998 State Council circular, they were dissolved in 1999.
} 
different financial institutions, from 1994 to 1997, a period when many key reform initiatives were introduced. The main analysis decomposes these changes into changes in loan repayment performance, inter-regional fund flows, and deposit mobilization. In section 5, we analyze the relationship between bank governance, or institutional practices, and loan repayment performance to better assess the reasons for different outcomes in rich and poor areas. We discuss reforms and performance since 1997 in section 6 and summarize the main results and discuss policy implications in section 7.

\section{Survey data}

Our data come from surveys we conducted of RCCs and township branches of the ABC in four provinces. ${ }^{4}$ These township-level institutions are the lowest tier of China's hierarchical banking structure and account for the large majority of formal lending in rural areas. ${ }^{5}$ The surveys were conducted in 1998 in two affluent coastal provinces (Zhejiang and Jiangsu), known for their highly successful township and village enterprises, and in 1999 in two poor interior provinces (Sichuan and Shanxi), where the rural economy relies more on agriculture and labor out-migration. Mean income per capita (in 1997) in surveyed townships was highest in Zhejiang (4470 yuan), followed by Jiangsu (3650 yuan), Sichuan (2060 yuan) and Shanxi (1558 yuan). ${ }^{6}$

In each province, a representative sample of counties was selected from different regions of the province and in areas with different levels of economic and industrial development. Eight counties were selected in Jiangsu, seven in Zhejiang, and six in both Sichuan and Shanxi. Within each county, four townships were randomly selected after stratifying by industrial output per capita. In total, 108 townships in 27 counties were chosen, and all $\mathrm{ABC}$ branches and RCCs in these townships were surveyed. Not all townships have $\mathrm{ABC}$ branches so the sample of $\mathrm{ABC}$ branches is smaller than the sample of RCCs. Most of the information was garnered from face-to-face interviews with bank

\footnotetext{
${ }^{4}$ The surveys in Zhejiang and Jiangsu were supervised by Li Hongbin and Shen Minggao, who we thank for this work and for processing the data. The surveys in Sichuan and Shanxi were supervised by Wang Sangui.

${ }^{5}$ Our survey estimates that 78 percent of bank loans within the township were granted by these two financial institutions in the coastal provinces, and xx percent in the interior provinces.

${ }^{6}$ The 1998 China Statistical Yearbook reports 1997 rural income (living expenditures) per capita of 3684 (2839) yuan in Zhejiang, 3270 (2488) yuan in Jiangsu, 1681 (1440) yuan in Sichuan, and 1738 (1145) yuan in Shanxi.
} 
managers, and available historical data on assets, liabilities, income, and expenditures were copied from accounting books. Basic economic data, including township income per capita, was also collected from each township government.

In this paper we restrict attention to financial institutions that have complete data for all variables required to decompose the changes in financial intermediation performance from 1994 to 1997. Because the surveys in Sichuan and Shanxi were conducted a year later, an additional year of data was collected (for 1998).

The data have several unique features. First, the data cover a period of major reform in China's financial system and in the operation of China's rural financial institutions. Second, the surveys provide very detailed information on financial performance, regulation, and governance of China's rural financial institutions. Third, the surveys in rich and poor provinces provide an excellent basis for a regional comparison of financial performance and bank behavior, facilitating a study of the distributional consequences of financial reform.

\section{Financial reform and China's rural financial institutions}

China's two main rural financial institutions, the ABC and RCCs, accounted for 14 and 12 percent of deposits, respectively, in all financial institutions in 2001 and a similar share of loans. The ABC is one of China's four specialized banks, with the largest branch network among specialized banks, extending to most but not all townships. Most lending is in the form of working capital loans for state commercial enterprises, but significant shares also are lent to township and village enterprises (TVEs), ${ }^{7}$ and to agriculture (including households). The RCCs are cooperatives in name only, not in governance. Originally under the supervision of the ABC, since 1996 they have been under the administrative supervision of the Peoples Bank of China. RCCs are the only financial institutions with branch outlets extending to nearly all townships as well as many villages. They are by far the most important source of formal credit in rural areas, lending over half of their funds to rural enterprises and most remaining funds to rural households.

\footnotetext{
${ }^{7}$ Following Chinese conventions, we define TVEs to include both collective and private enterprises.
} 
The political, economic, and regulatory environment in which local ABC branches and RCCs operate is an important backdrop to our analysis of their performance. Historically, ABC branches were a source of policy loans for the rural sector, mainly for agricultural commodity procurement. Although these policy loans were transferred to the Agricultural Development Bank of China (ADBC) in 1994, ${ }^{8}$ ABC branches and RCCs have not been immune to local political pressure, especially from local government officials keen to support revenue-generating industrial projects. ABCs also carry a small portfolio of explicit policy loans (including poverty alleviation loans) and on occasion are pressed to support state marketing agencies. Nonetheless, most managers in both institutions report that by 1994 profitability had become the most important criteria for approving loans. This commercial orientation increased steadily over time. A Commercial Banking Law was passed in 1995 that strengthened managerial performance incentives in state-owned banks. By 1997, profits were overwhelming the main stated concern of ABC and RCC bank managers (Park and Shen, forthcoming). Overall, we expect less policy lending in rural financial institutions than in other large specialized banks and policy banks, and for policy lending to decline over time.

Despite efforts to increase profit incentives, most bank managers operate in a highly circumscribed regulatory environment. All deposit and lending interest rates are controlled at below market-clearing levels, adjustable within relatively narrow margins. After nearly uncontrolled inter-bank lending in the early 1990s, the government shut down, and subsequently reformed, the inter-bank market in 1993. Participation in the inter-bank market, which reopened in 1996, is tightly restricted to the headquarters of major financial institutions. Currently, most transfers of financial resources of local branches are through vertical deposits of surplus funds in higher-level branches of the same bank. Thus, township ABC branches deposit funds with the county ABC branch, and RCCs deposit funds with the county RCC association (lianhehui). ${ }^{9}$ Aside from local lending, managers have virtually no alternative options for fund use.

\footnotetext{
${ }^{8}$ The Agricultural Development Bank of China (ADBC, or nongye fazhan yinhang) separated from the ABC as one of three policy banks established in 1994, with branches at the county level. In 1996, the ADBC accounted for 10 percent of national lending. Ninety percent of loans were for agricultural procurement, mainly grain.

${ }^{9}$ The ABC is a national bank, implying the potential for inter-regional transfers, but transfers among RCCs typically occur only among branches within the same counties.
} 
Lending by bank managers is further restricted by credit quotas, which are typically based on a county plan or with increasing frequency on an agreement linking lending amounts to the amount of deposits. In most cases, however, the quota can be marginally adjusted if the manager can justify the need for more funds. Since 1995, all official plans have been "guidance" or recommended plans rather than "indicative" or mandatory ones. Managers also are often restricted in the size of loans that can be issued without authorization from the county ABC branch or RCC association. Local discretion in individual loan decisions has decreased over time (Shen and Park, 2001). County branches play an important role in regulating and supervising township bank branches, although the township banks remain independent accounting units. Thus, upper level banks play a key role in intermediating funds across regions.

In Table 1, we provide summary balance sheet information from the rural financial institutions we surveyed. Financial institutions differ considerably in terms of size, with those in the richest quartile of our regions, for example, nearly eight times as large as those in the poorest quartile. The rural financial institutions in Zhejiang are significantly larger than those in the other three provinces, and $\mathrm{ABC}$ branches are bigger than RCCs. Deposits are the primary source of funds. Between 1994 and 1997, the ratio of deposits to total assets increased from 58 percent to 64 percent. In poor areas, the deposit shares are particularly high, suggesting that deposit mobilization may play a more critical role in determining the amount that financial institutions in such areas can lend.

Most rural lending is to firms, not farmers. This suggests that richer areas require greater financing since they have more firms, which in general are more capital-intensive. In our sample, 65 percent of outstanding loans went to firms in 1994 and 68 percent in 1997 (Table 1). However, in the poorest quartile where the non-agricultural sector is much less developed, less than 40 percent of loans go to enterprises and share decreased from 1994 to 1997. RCCs lend more to firms than do ABC branches, but between 1994 and 1997 the difference between the two institutions narrowed. For Sichuan and Shanxi, we have a more detailed breakdown of lending categories (Appendix Table 1). Enterprise lending is predominant in Sichuan while household lending is dominant in 
Shanxi. RCCs lend a much greater share of funds to enterprises than ABCs. ${ }^{10}$

Household lending also comprises a much higher share of lending in poorer townships (over two-thirds in the poorest quartile in 1998), largely reflecting the weakness of the enterprise sector in such areas. Between 1994 and 1998, the percentage of lending to firms in the richest quartile increased; however, in the three remaining quartiles, an increasing share of loans went to households. These findings are consistent with other research that finds that a relatively high proportion of farmers in poor regions have at least some access to formal credit (Park and Wang, 2000). Ironically, it may be households in richer areas that have greater difficulty obtaining individual loans because banks so prefer lending to enterprises. ${ }^{11}$

\section{Changes in financial intermediation in rich and poor areas from 1994 to 1997}

\section{Financial intermediation}

To assess whether China’s financial reforms are leaving poor regions behind, we require a financial performance measure that enables us to compare the extent of financial intermediation in rich versus poor areas over time. Financial development is frequently measured by the amount of financing normalized by the value of economic output, e.g., the ratio of total loans to GDP. In this paper, we restrict attention to formal financial intermediation in the form of credit, excluding equity financing and informal borrowing. $^{12}$

Because GDP is not calculated at the township level in China, we use the ratio of outstanding loans per capita to rural income per capita. Income per capita is a net rather than gross measure and does not include retained earnings in enterprises, village collective income, or other income not accruing to households. Insofar as GDP per capita in China during this period is positively correlated with the size of the local collective sector, our income measure could underestimate the level of development. Relative to a

\footnotetext{
${ }^{10}$ This is likely due to significant lending by ABCs to marketing agencies such as supply and marketing cooperatives (gongshaoshe) and grain trading companies (liangshi maoyi gongsi).

${ }^{11}$ This may be offset by the fact that richer households have greater savings (and deposits) and so generally are better able to self-finance common expenditures such as fertilizer and school fees. From this perspective, household credit demand does not necessarily rise with income.

${ }^{12}$ During this period, TVEs could not be listed in capital markets. Informal borrowing is probably at least as important as formal financing for households in rural areas (Park, Brandt, Giles,, 1997) but relatively unimportant for firms.
} 
measure using GDP, this could lead us to overstate the linkage between the level of development and depth of financial intermediation.

We also make a second adjustment. The portfolios of many banks in China have large amounts of overdue loans with dubious repayment prospects. If loans that should be written off as losses are kept on the books, they can present a misleading picture of the true extent of financial intermediation and net flow of funds. Fortunately, our survey provides information on overdue, or non-performing loans. We thus divide total outstanding loans into "performing” and "non-performing” loans. Even though some overdue loans may provide a meaningful intermediation function, we consider the amount of performing loans relative to income to be a superior measure of effective financial intermediation.

In Table 2, we report financial intermediation levels for 1994 and 1997 using both total outstanding loans and performing loans. There does not appear to be a strong pattern of effective financial intermediation (using performing loans) across income groups in 1994, although the richest income quartile does have the greatest effective intermediation. By 1997, however, the pattern looks fairly systematic, with effective intermediation rates increasing with higher income levels. This suggests that rich areas gained relative to poor areas over this period, which is confirmed by looking at the change in effective intermediation rates for each income quartile. The lower income quartiles suffer quite striking declines in effective intermediation, from 31 and 30 percent in 1994 to 24 and 23 percent in 1997, while the richer quartiles see negligible changes. If we look at intermediation rates using total outstanding loans, the patterns just described are much less pronounced. However, it is still the case that the richest quartile sees increasing intermediation from 1994 to 1997 while the other groups see decreasing intermediation. Part of the reason for the lack of clear trends is the large provincial differences in intermediation rates. In 1994, using either measure of intermediation, Shanxi (Jiangsu) exhibits the highest (lowest) level of intermediation.

To see more clearly how different factors influence the extent of effective financial intermediation in localities, we decompose our measure of effective financial intermediation in the following way: 


$$
\frac{P L}{Y}=\frac{P L}{L} \times \frac{L}{D} \times \frac{D}{Y}
$$

where PL is performing loans, $\mathrm{Y}$ is income, $\mathrm{L}$ is total outstanding loans, and $\mathrm{D}$ is deposits. The rate of effective financial intermediation at any given point in time is the product of the share of performing loans in total loans, the loan to deposit ratio, and the ratio of deposits to income. These three variables measure loan performance, net fund flows, and deposit mobilization, respectively, and are all positively correlated with effective financial intermediation rates.

In Tables 3, 4 and 5, we provide summary information for each of these variables in 1994 and 1997 organized by income group, province, and bank type. This is supplemented by regression results reported in Table 6, which test if these financial performance variables are significantly correlated with income per capita levels after controlling for other factors.

\section{Loan Performance}

Non-performing loans include three categories: overdue, inactive (overdue for more than 2 years), and dead (overdue for more than 3 years or confirmed for other reasons to be unrecoverable). Most non-performing loans are classified as overdue, but nearly half fall in the two more delinquent categories. Clearly, the problems that banks currently face are a product of past lending decisions. In 1994, the share of outstanding loans that were overdue in the full sample was 17 percent; by 1997, this had increased to 24 percent (Table 3). These estimates of non-performing loans are comparable to the 22 percent figure cited by Lardy (1998) for China’s four large state-owned banks in $1995 .^{13}$

The non-performing rates are substantially higher in poorer townships and provinces. $^{14}$ In 1994, non-performing in the bottom two quartiles were 23 and 32 percent, while in the upper two quartiles they were only 13 and 19 percent. The nonperforming rates in Sichuan and Shanxi were 24 and 30 percent, and only 12 percent

\footnotetext{
${ }^{13}$ Note however that both estimates may understate the true magnitude of the repayment problem if banks roll over loans through “ever-greening” or otherwise conceal repayment problems (Lardy, 1998).

14 The full sample average reflects the greater number of financial institutions surveyed in the coastal provinces and the greater amount of funds per financial institution.
} 
in Zhejiang. In 1997, the problem of non-performing loans continued to be the most severe in the poorer provinces and income quartiles, with 43 percent of all loans overdue in the lowest quartile. Looking at trends, the richest quartile surprisingly saw the largest increase in nonperforming loans, probably because of poor enterprise performance, while the second quartile was the only one to achieve better performance over time.

Are funds flowing out of poor areas?

We measure the net flow of funds by the ratio of outstanding loans to deposits in each financial institution. If deposits were the only source of funds, a financially selfsufficient bank should have a loan-deposit ratio less than one because of reserve requirements. Peoples Bank of China (PBC) regulations mandate reserves of 13 percent of loans for all financial institutions. This can be higher for some local branches, especially RCCs before 1996 when they were regulated by ABCs. Higher loan-deposit ratios imply that more local resources are being lent locally rather than being intermediated for use in other areas, which occurs when branches deposit funds in higher level branches, lend on the inter-bank market, or buy government bonds. Banks borrowing funds from their headquarters or from other banks through an inter-bank market could, in principal, have loan-deposit ratios exceeding one. If funds tend to flow out of poor and into rich areas, we expect poor (rich) areas to have lower (higher) loandeposit ratios. This, in turn, would contribute to lower (higher) intermediation rates in poor (rich) townships.

Table 4 presents loan-deposit ratios broken down by income per capita quartile, province, and bank type. In 1994, the loan-deposit ratio in our sample of banks was 0.71 , falling to 0.64 in 1997. This decline is in line with that observed for all financial institutions nationwide, which experienced a drop in the ratio of loans to deposits from 1.01 to 0.91 over this same period (China Financial Yearbook 1999). ${ }^{15}$ In 1994, the differences across the four provinces are relatively modest; however, the ratio is significantly lower in the lowest income quartile. In 1997, the gap between income groups narrowed, largely because of a pronounced decline in loan-deposit ratios in the

\footnotetext{
${ }^{15}$ The high loan-deposit ratios for all banks and its subsequent decline largely reflect re-lending by the People's Bank of China to state-owned banks, which through the 1980s accounted for as much as 30 percent of funds, but since the mid-1990s has tightened considerably.
} 
upper two income quartiles. In the poorest quartile, the percentage of deposits that was being lent out in 1997 was actually slightly higher than in 1994. Although differences in loan-deposit ratios narrowed across income quartiles, it remains the case that in both 1994 and 1997 lower loan-deposit ratios contributed to lower intermediation rates in the poorest quartile.

\section{Deposit mobilization}

We measure deposit mobilization by the ratio of deposits per capita to current income per capita. A high ratio could reflect a number of factors including high household savings rates over time as well as a high percentage of savings that are intermediated through formal financial institutions. ${ }^{16}$ A well-developed informal credit market or other sources of financial competition, as well as low savings rates, would have the opposite effect. Table 5 reports deposits and incomes per capita, and the ratio of the two. Considerable differences exist across provinces, but there is no clear pattern across income groups. In fact, deposit mobilization in 1994 is highest in the poorest quartile, followed by that in the richest. The former may reflect unobservable features of rich and poor areas (e.g., alternative investment options) or more limited opportunities in poor areas for households to use their own funds in activities such as family-run businesses. What is apparent from Table 5 is that richer townships experience an increase in the ratio of deposits to income but poorer townships see a decline. This should widen differences in financial intermediation between rich and poor regions.

\section{Financial intermediation and rural income per capita}

We can look more systematically at the relationship between financial intermediation and income levels by estimating multivariate specifications for the determination of effective intermediation rates and performance measures that affect the extent of intermediation. We regress these variables on the log of rural income per capita controlling for bank type, with and without controls for provincial differences. ${ }^{17}$

\footnotetext{
${ }^{16}$ Savings are a stock and reflect the accumulated behavior over time. Income, on the other hand, is a current flow.

${ }^{17}$ The specification without provincial controls includes a dummy variable for bank type. When controlling for provincial differences, dummy variables for provinces and bank type are interacted, so that
} 
Controlling for provincial differences, higher income per capita is significantly associated with higher intermediation rates, measured by either performing loans or total loans. This positive association is greater in 1997 than in 1994, suggesting increasing disparities associated with income levels. A one percent increase in income increased the effective financial intermediation rate by 0.15 percent in 1994 and 0.21 percent in 1997 (Table 6). However, dropping provincial controls, the relationships are no longer statistically significant.

We also examine the effect of income differences on loan performance, loandeposit ratios, and deposit mobilization. The effect of rural income per capita on loan performance increases from 1994 to 1997. With provincial controls, a one percent increase in income per capita increases the share of performing loans by 0.08 percent in 1994 and by 0.21 percent in 1997. When we drop controls for provincial differences, we find roughly similar results. There is a consistent negative relationship between incomes and the loan-deposit ratio, but this shows up significantly only in the specification without provincial controls, suggesting that these differences are due in part to differences in provincial characteristics other than average income, e.g., quality of alternative investment projects or financial regulation. Third, higher income per capita is associated with a more than proportionate increase in the deposit-income ratio. A one percent increase in income per capita is associated with an increase in the deposit-income ratio of 1.36 percent in 1994 and 1.79 percent in 1997. Without provincial controls, the effects are smaller but still significant.

Overall, the results suggest that the relationship between financial intermediation rates and income levels is stronger within provinces than between provinces. In other words, a poor township is worse off relative to a rich township in the same province than it is relative to an equally rich township in another province. In particular, provincial differences appear to be muting the measured response of per capita deposits and loans to income, which may be due to greater financial competition in these areas. One plausible explanation is that households in coastal provinces are more likely to deposit funds in other financial institutions or in other investment vehicles.

the effects of income per capita are identified by variation among banks of the same type in the same province. 
Decomposing the sources of change in financial intermediation between 1994 and 1997

Table 2 reveals a marked deterioration in effective intermediation in poorer areas. Although all provinces experienced a decline in the rate of effective intermediation between 1994 and 1997, the deterioration was most severe in Sichuan and Shanxi. This decline is generally mirrored in the behavior of the bottom two quartiles, in which the share of performing loans fell from 0.31 to 0.23 . In terms of growth rates, the effective financial intermediation rate fell at an annual rate of 8.1 and 9.1 percent in the bottom two quartiles. In the upper quartile, it fell by only 2.0 percent per year, while it actually rose slightly by 0.9 percent per annum in the second quartile.

From (1), it is straightforward to express the change in the effective intermediation rate as the sum of the growth rates of its components:

$$
\begin{aligned}
\log \left(\frac{P L_{97}}{Y_{97}}\right)-\log \left(\frac{P L_{94}}{Y_{94}}\right)= & \left\{\log \left(\frac{P L_{97}}{L_{97}}\right)-\log \left(\frac{P L_{94}}{L_{94}}\right)\right\}+\left\{\log \left(\frac{L_{97}}{D_{97}}\right)-\log \left(\frac{L_{94}}{D_{94}}\right)\right\} \\
& +\left\{\log \left(\frac{D_{97}}{Y_{97}}\right)-\log \left(\frac{D_{94}}{Y_{94}}\right)\right\}
\end{aligned}
$$

The difference in logs for each variable is equal to the exponential growth rate, which can be annualized by dividing by the number of years. Table 7 summarizes the annual growth rates in (2) and reports the percentage of the overall rate of change in effective financial intermediation accounted for by each factor.

Two factors contributed fairly evenly to the sharp decline in effective intermediation in the poorest two quartiles: the deterioration in the performing component of the loan portfolio, and the much slower growth of deposits relative to the growth in incomes. It is, of course, possible that the bad loan performance and low deposit mobilization in poorer areas are related, if depositors lose confidence in institutions perceived to be in financial distress. We have no direct evidence on whether this is in fact the case. Between 1994 and 1997, deposit growth was only half that of reported income in poorer areas, despite the fact that poor areas had significantly higher levels of deposit mobilization in 1994. In the richest quartile, on the other hand, the share 
of performing loans also fell sharply, as did the loan-deposit ratio. This was largely offset, however, by the rapid growth in deposits in local financial institutions relative to income growth. In the second income quartile, on the other hand, we actually see a small increase in intermediation rates. An improvement in the loan portfolio and rapid deposit growth more than made up for the decline in the loan-deposit ratio over this three-year period so that the rate of growth of performing loans exceeded that of incomes.

\section{Bank governance and loan performance}

The high and increasing percentage of non-performing loans is an essential component of the intermediation failure we have described in poorer areas. How much of this can be linked to problems in bank governance? In this section of the paper, we examine the links between non-performing loans and governance structures, and the conditions that lead to changes in governance structures.

From the bank surveys, we capture governance in a variety of ways, including loan authorization limits of branch managers; ex-ante bonus incentives of branch mangers measured as a percentage of the manager's base wage; the percentage of loans with collateral; government pressure to renegotiate overdue loans; quarterly reporting requirements of branches; and the time required to resolve overdue loan issues through the courts. A priori, we associate more powerful income incentives, the use of collateral, freedom from government intervention, stricter and more frequent reporting requirements, and the ability to take legal action against defaulting borrowers as key ingredients of better governance structures. Managerial autonomy to make loans can also be a key component of bank governance, especially when combined with income incentives that penalize bad managers for making bad loans and reward them for decisions that increase branch profitability. Unconstrained autonomy, however, can lead to moral hazard problems that might undermine banking profitability and efficiency. We expect better governance, in turn, to translate into a lower percentage of non-performing loans.

Simple descriptive statistics on all of the governance-related variables are presented in Table 8, which breaks the data down by income quartiles of the townships. We report both levels in 1997 and changes between 1994 and 1997. The much larger 
sample size for the former reflects the more complete information we have for $1997 .{ }^{18}$ In some important respects, poor areas appear to be handicapped by poorer institutional practices. The size of loans that can be approved is much lower in the poorest areas, collateral requirements and reporting requirements are more lax, and government influence on lending is higher. However, there are other aspects that favor poor areas. Bonus incentives are stronger, perhaps reflecting budgetary shortages, and the time it takes to complete lawsuits is shorter, perhaps because there are fewer cases backlogging the system given lower levels of economic activity. In general, changes in governance variables is occurring more rapidly in richer areas compared to poorer areas.

Table 9 reports the results of OLS regressions analyzing the percentage of nonperforming loans in 1997 as a function of bank governance variables in 1997, and the change in non-performing loans between 1994 and 1997 as a function of governance variables in 1994. We recognize the multiple endogeneity problems associated with relating institutional change and economic performance, so treat the relationships more as correlations rather than making strong causal inferences. Columns 5-8 of Table 9 report the results linking non-performing loans in 1997 to bank governance. In each of the regressions, we also include township per capita income as an additional control variable. For comparison, column 5 reports the results of the bivariate regression of nonperforming loans on income. The regressions are nicely suggestive of the role of governance. We find that the percentage of non-performing loans is negatively correlated with branch manager bonus incentives, the use of collateral, freedom from government pressure, and authorization limits (insignificantly), and positively correlated with the length of time required to resolve cases legally. The percentage of non-performing loans is also significantly lower in higher income areas. This may be picking up overall higher loan quality, and possibly unobserved dimensions of local governance structures that are correlated with incomes. ${ }^{19}$

In column 7, we include as an additional explanatory variable the interaction between loan authorization limits and managerial bonus incentives. As in column 6, the

\footnotetext{
${ }^{18}$ Frequent managerial turnover in the bank branches handicapped our efforts to obtain information for 1994.

${ }^{19}$ The results are robust to including provincial fixed effects, controlling for branch type, and to excluding the income variable.
} 
individual coefficients on these two variables remain negative, and now are significant at 5 percent. The positive coefficient on the interaction term, however, suggests that a combination of high authorization limits and powerful incentives contributes to a weakening of the quality of the loan portfolio. One interpretation for this result is that the combination leads to excessive risk-taking on the part of branch managers that ultimately lead to an increase in the percentage of non-performing loans. It also suggests the need for higher authorities to properly balance incentives and prudential regulation.

In columns 1-4, we analyze the effect of governance structures present in 1994 on the change in non-performing loans between 1994 and 1997. We also include township income in 1994, and in column 4, add the level of non-performing loans in 1994. Limited information on governance in 1994 restricts our attention to a much smaller set of variables than used above, and to a relatively small sample of RCC and ABC branches. The results are informative, however. First, governance seems to matter. The increase in non-performing loans is smaller in townships in which government influence is less, there is more frequent reporting to higher level county branches, and managers have more discretion in extending new loans. Second, the increase is less in townships with higher incomes. Since the change in non-performing loans is not correlated with the growth in our income measure (result not reported here) over the same period, one interpretation for this result is that the income variable is picking up "unobserved" dimensions of governance at the township level that are positively correlated with incomes. Third, we find that the increase in non-performing loans over this three-year window is lower in branches with a higher stock of non-performing loans of 1994. This may reflect additional actions being taken by these branches to address the non-performing loan problem. Note that the inclusion of the stock of non-performing loans in the regression does not significantly affect the remaining coefficients.

In Table 10, we examine changes in governance levels between 1994 and 1997. We keep the regressions simple and examine the effect of incomes in 1994, the level of governance in 1994, and the stock of non-performing loans in 1994 on the changes in governance between 1994 and 1997. Three key questions motivate this exercise: first, are the changes in governance greatest where they are most needed, i.e. branches with the highest stock of non-performing loans; second, are governance structures converging 
across localities; and third, are poorer areas lagging behind in the pace of reform, all else held constant?

In general, it appears that there is some convergence as suggested by the negative coefficients on the governance variables in 1994. The overall trend appears to be toward better governance, with the greatest changes occurring in those areas with lower measures of governance in $19944^{20}$ For three of the five governance variables (loan authorization, incentives, and reporting requirements), it is also the case that the improvement in governance is positively related (but not statistically significant) to the stock of non-performing loans in 1994. In other words, the changes are greatest where they are probably most needed. However, government pressure on branches appears to be increasing in areas with a higher stock of non-performing loans. The likely reason for this correlation is that it reflects government efforts to obtain relief for firms under their administration. Contrary to our expectation, we also find that the increase in the use of collateral appears to be lower in areas with a higher stock of non-performing loans. Finally, it also appears that with the exception of bonus incentives, the changes in governance are occurring most rapidly in higher income areas.

What are then the implications of our analysis for poorer areas? Several things bode well. First, localities with higher stocks of non-performing loans appear to be slightly more aggressive in carrying out reform. Since it is poorer regions that have the highest stock of non-performing loans, this suggests that governance reform in these regions may be responsive to the pressures of non-performing loans. Second, the increase in non-performing loans is smaller the higher the stock of bad loans in 1994. This may be picking up some of the benefits of the improvement in government structures reported above. Yet possibly counteracting some of these trends is the tendency for changes in governance to be greatest in localities with the highest incomes. Despite better overall governance in these regions, the need for governance reform remains high.

\section{Performance since 1997}

\footnotetext{
20 This result should be interpreted carefully, however, because a regression of a change in a variable on its lagged value automatically imparts a negative bias. A number of the variables are also truncated. Unfortunately, there is not much we can do to correct these problems.
} 
Since 1997, a number of new reforms have been undertaken that have affected the allocation of loans in rural China. ${ }^{21}$ For RCCs, these include new low-interest lending to RCCs by the People's Bank of China to support agricultural loans by RCCs beginning in 1997 and a new micro-loan program for rural households featuring credit ratings for individual households beginning in $1999 .^{22}$ The People’s Bank of China also has begun experiments to liberalize interest rates in 8 counties nationwide, and in a province-wide experiment has allowed township-level RCCs in Jiangsu to be merged into county unions, some of which have been converted to rural commercial banks. The share capital of RCCs has also been increased to make RCCs more financially viable and to allow them to be managed more like true cooperatives (i.e., to improve governance).

Table 11 reports on the financial performance of RCCs in poor regions of Sichuan and Shanxi from 1997 to 2002 based on data from over 100 township-level RCCs in the two provinces. This sample is unrelated to the sample of banks surveyed in 1998 in the same provinces. The trend toward greater reliance on own deposits as a source of funds seems to reverse itself by 1999, and lending as a share of total liabilities also peaks in 1999. These trends may in part reflect new sources of on-lending from the PBC. Loandeposit ratios rise and fall for Sichuan and exhibit no obvious pattern in Shanxi.

Consistent with earlier trends, starting in 1997 the share of outstanding loans that are nonperforming (overdue) increased in both Sichuan and Shanxi, reaching 68 percent in Sichuan and 75 percent in Shanxi. The large increases in nonperforming loans in 1999 was likely due to mergers with disbanded RCFs. However, the worsening trend finally reversed after 2001 in Sichuan and after 2000 in Shanxi, and there is noticeabe improvement in loan performance thereafter. This is consistent with reports showing that nationally RCCs reduced their nonperforming loans by 5 percent in $2001 .^{23}$ In addition to better screening and enforcement of loan repayment, some of this improvement may be due to PBC infusions of funds to take NPLs off of the books and profit opportunities from new PBC lending to RCCs. A study of the Jiangsu experiment has found that

\footnotetext{
${ }^{21}$ The reforms described in this paragraph come from Xie (2002).

${ }^{22}$ After investigation by a credit rating task force, credit certificates are given to households which allow households to borrow without restriction up to the defined credit limit as long as they successfully repay loans.

${ }^{23}$ Recent Chinese articles report improved performance in 2001 and 2002 in Shandong, Zhejiang, and Hubei provinces (Bai, 2002; Liu, 2002; Gong, 2002).
} 
further performance gains may be realized by organizational reforms that merge township RCCs into county RCC unions, which facilitates better intermediation of funds across regions (Cheng and Chu, 2002).

Table 11 also reveals that the share of RCC lending to households and agriculture increased from 68 percent in 1997 to 73 percent in 2001 in Sichuan and from 55 percent in 1997 to 62 percent in 2002 in Shanxi. Lending to enterprises remained relatively stable in Sichuan but fell in Shanxi. Improved loan performance and greater propensity to lend to households suggests that credit access to households in poor areas likely improved in the most recent period. It also suggests that governance reforms and institutional innovations (e.g., household credit ratings) have made lending in poor areas more profitable than before. However, important aspects of governance in rural financial institutions, especially RCCs, remain unresolved, such as whether RCCs should be governed as cooperatives or commercial banks and how remaining historical bad debts should be resolved (Watson, 2002).

\section{Conclusions}

We summarize some of the main findings from the empirical analysis:

1. The ratio of loans to income, a measure of financial intermediation, was stable in rich areas but fell in poor areas. The ratio of performing loans to income, a better measure of effective intermediation, fell in all areas, but much more rapidly in poor areas.

2. Non-performing loans are significant in all areas, but greater in poor areas. They have increased over time in all regions, but faster in the richest and poorest areas. While the share of household loans that are non-performing has remained high but relatively stable, the share of TVE loans that are non-performing has increased rapidly to exceed that of household loans.

3. Loan-deposit ratios, measures of net fund outflow, are lower in rural financial institutions than in all banks and lower in poor areas than in rich areas. They have 
declined over time at a rate similar to that of all banks, but have declined more in richer areas.

4. Income per capita grew faster in poor areas relative to rich areas, but deposits grew slower.

5. Financial institutions in poor areas showed a greater willingness to lend to households and this relative trend strengthened over time.

6. The non-performing loans problem is closely tied to institutional practices, or bank governance. While banks with greater repayment problems are reforming faster all things equal, it is still the case that richer areas tend to have better governance and to be reforming faster.

If we consider the motivating question for the paper and its title, the most accurate answer is affirmative, but not for the anticipated reason, i.e., greater fund flows out of poor areas. While the increase in non-performing loans is undermining financial intermediation throughout rural China, the problem is worse in poor areas because of slower deposit growth and more serious repayment problems. However, the way the motivating question is posed may be misleading because these changes are not so much the result of financial reform as the inability of reform to reduce non-performing loans even as many regulations (especially interest controls and restrictions on interbank lending) continue to constrain the decisions of bank managers and link lending volume closely to local resources (deposits). If this, in fact, is what is happening, or rather not happening, there is still ample scope for new changes and new distributional consequences as China continues to liberalize the financial sector in anticipation of WTO entry.

To draw policy implications, it is important to understand the reasons for poor loan performance, especially in poor areas. If poor performance reflects the lack of good projects, the efficiency-equity tradeoff becomes quite stark, and policy-makers might be best advised to improve the economic environment to make investments more desirable. 
However, if poor performance reflects institutional failings of financial institutions in remote areas, either because of stifling regulation or poor management, there may be greater scope for reforms that can advance both equity and efficiency goals. While many identification problems make our empirical results more suggestive than definitive, we do find evidence that both the quality of projects and institutional practices matter. Some of the trends in the speed of institutional reforms are encouraging, others disquieting. Nonetheless, the evidence suggests there may be scope for improved performance with possibly beneficial distributional consequences from continued reforms. Indeed, the recent improvement in RCC loan performance nationwide and in poor regions in particular, which likely resulted in part from governance reforms and institutional innovations, provides additional encouraging evidence. The early experience of microfinance institutions operating in China’s poor areas also has been very positive, supporting the notion that institutional reform and greater regulatory flexibility may encourage financial institutions to lend successfully in poor areas (Park and Ren, 2001).

The prognosis for the future depends very much upon reforms that have yet to occur in China, in particular greater opening of the inter-bank market and interest rate liberalization. If the former occurs without the latter, the effects could be quite negative for poor areas. Lending to the poor is unlikely to be profitable unless interest rates are allowed to be higher than in other areas in order to compensate for the higher administrative costs and other risks. In this light, recent experiments with interest rate liberalization may be critical for keeping funds from flowing from poor areas even though higher interest rates could reduce credit demand. Underlying institutional development to better enforce contracts, share credit histories, increase the effectiveness of collateral and guarantors as security for loans, increase the quality of managers and loan officers, and provide appropriate incentives will support more effective financial intermediation in both rich areas and poor, but their importance to lending in poor areas may be even greater because of the greater institutional challenges to banking with the poor. 


\section{References}

Bai, Shichun. 2002. "Fully Enable Rural Credit Cooperatives to be the Leading Force to Support Agriculture (chongfen fahui nongcun xinyongshe zhinong zhulijun zuoyong),” China Finance (zhonguo jinrong) 9: 25-26.

Besley, Timothy. 1994. "How do Market Failures Justify Interventions in Rural Credit Markets?” The World Bank Research Observer 9(1): 27-47.

Brandt, Loren, and XiaodongZhu. 2000. "Redistribution in a Decentralized Economy: Growth and Inflation in Reform China.” Journal of Political Economy 108(2): 422-439.

Brandt, Loren, and Hongbin Li. forthcoming. "Bank Discrimination in Transition Economies: Ideology, Information or Incentives?” Journal of Comparative Economics.

China Financial Yearbook 1999. 2000. (Beijing: China Financial Press).

China Statistical Yearbook 1998. 1999 (Beijing: China Statistics Press).

Cheng, Enjiang, and Baojin Chu. 2002. The Reform of China's Rural Credit

Cooperatives: Financial Performance, Subsidies and Policy Implications: The Case of Jiangsu, mimeo.

Gertler, Mark, and Andrew Rose. 1996. "Finance, Public Policy, and Growth,” in Gerard Capri, Jr., Izak Atiyas, and James Hanson, eds., Financial Reform: Theory and Experience (New York: St. Martin’s Press), pp. 115-128.

Gong, Fangle. 2002. Zhejiang Province Rural Credit Cooperative Reform Model Experiment (zhejiang sheng nongcun xinyongshe gaige moshi tansuo), http://www.drcnet.com.cn.

King, Robert, and Levine, Ross. 1993. "Finance and Growth: Schumpeter Might Be Right.” Quarterly Journal of Economics 108, 3:713-37.

Kraay, Aart. 2000. "Household Saving in China,” TheWorld Bank Economic Review 14(3): 545-570.

Lardy, Nicholas. 1998. China's Unfinished Economic Revolution (Washington, D.C.: Brookings Institution Press).

Levine, Ross. 1997. "Financial Development and Economic Growth: Views and Agenda.” Journal of Economic Literature 35, 2:688-726.

Levine, Ross, and Zervos, Sara. 1998. “Stock Markets, Banks, and Economic Growth.” American Economic Review 88, 3:537-58. 
Liu, Zhigao, et al. 2002. "Separate Account Management: Attempt to Successfully Recover Nonperforming Loans of Rural Credit Cooperatives (panhuo xinyongshe buliang daikuan de chenggong changshi)," Finance Reference (jinrong cankao) 9.

Morduch, Jonathan. 2000. “The Microfinance Schism," World Development 28(4): 617628.

Naughton, Barry. 1995. Growing Out of the Plan: Chinese Economic Reform, 1978-92 (Cambridge: Cambridge University Press).

Nyberg, Al, and Scott Rozelle. 1999. Accelerating China's Rural Transformation (Washington, D.C.: The World Bank).

Park, Albert, Loren Brandt, and John Giles. 1997. Giving Credit Where Credit is Due: The Changing Role of Rural Financial Institutions in China, William Davidson Institute Working Paper No. 71.

Park, Albert, Loren Brandt, and John Giles. forthcoming. "Competition Under Credit Rationing: Theory and Evidence from Rural China, Journal of Development Economics.

Park, Albert, and Minggao Shen. forthcoming. "Joint Liability Lending and the Rise and Fall of China's Township and Village Enterprises,” Journal of Development Economics.

Park, Albert, and Changqing Ren. 2001. "Microfinance with Chinese Characteristics," World Development 29(1): 39-62.

Park, Albert, and Kaja Sehrt. 2001. "Tests of Financial Intermediation and Banking Reform in China,” Journal of Comparative Economics 29: 608-644.

Park, Albert, and Sangui Wang. Will Credit Access Help the Poor?: Evidence from China, mimeo.

Putterman, Louis. 1992. "Dualism and Reform in China," Economic Development and Cultural Change 40(3): 467-493.

Rajan, Raghuram, and Zingales, Luigi. 1998. "Financial Dependence and Growth.” American Economic Review 88, 3:559-86.

Sehrt, Kaja. 1999. Banks Versus Budgets: China’s Financial Reforms 1978-1996, Ph.D. dissertation, Department of Political Science, University of Michigan.

Shen, Minggao, and Albert Park. 2001. Decentralization in Financial Institutions: Theory and Evidence from China, mimeo.

Watson, Andrew. 2002. Financing Farmers: the Reform of the Rural Credit Cooperative and the Provision of Financial Services to Farmers, mimeo. 
Wong, Christine, Christopher Heady, and Wing Woo. 1995. Fiscal Management and Economic Reform in the People's Republic of China (Hong Kong: Oxford University Press).

Xie, Ping. 2002. Reforms of China's Rural Credit Cooperatives and Policy Options, mimeo. 
Table 1

Rural Financial Institution Balance Sheet Summary Statistics, 1994 and 1997

\begin{tabular}{|c|c|c|c|c|c|c|c|c|c|}
\hline & & & & & & & & & \\
\hline & $\mathrm{N}$ & $\begin{array}{l}\text { Assets } \\
\text { (million } \\
\text { yuan) }\end{array}$ & $\begin{array}{l}\text { Dep./ } \\
\text { Assets }\end{array}$ & $\begin{array}{l}\text { Loans/ } \\
\text { Assets }\end{array}$ & $\begin{array}{l}\text { Loan } \\
\text { share to } \\
\text { firms }\end{array}$ & $\begin{array}{l}\text { Assets } \\
\text { (million } \\
\text { yuan) }\end{array}$ & $\begin{array}{l}\text { Dep./ } \\
\text { Assets }\end{array}$ & $\begin{array}{l}\text { Loans/ } \\
\text { Assets }\end{array}$ & $\begin{array}{c}\text { Loan } \\
\text { share to } \\
\text { firms }\end{array}$ \\
\hline Full sample & 125 & 4641 & 0.573 & 0.408 & 0.654 & 8204 & 0.630 & 0.406 & 0.678 \\
\hline Income quartiles & & & & & & & & & \\
\hline $\mathrm{I}$ & 31 & 9493 & 0.532 & 0.376 & 0.708 & 17178 & 0.578 & 0.365 & 0.731 \\
\hline II & 32 & 4776 & 0.508 & 0.393 & 0.561 & 9384 & 0.570 & 0.375 & 0.611 \\
\hline III & 31 & 3019 & 0.699 & 0.511 & 0.752 & 4335 & 0.830 & 0.583 & 0.776 \\
\hline IV & 31 & 1270 & 0.834 & 0.455 & 0.376 & 1880 & 0.945 & 0.534 & 0.349 \\
\hline Provinces & & & & & & & & & \\
\hline Zhejiang & 30 & 11440 & 0.462 & 0.339 & 0.731 & 18945 & 0.554 & 0.383 & 0.682 \\
\hline Jiangsu & 43 & 3314 & 0.694 & 0.496 & 0.562 & 7223 & 0.657 & 0.379 & 0.718 \\
\hline Sichuan* & 21 & 2168 & 0.775 & 0.505 & 0.621 & 3416 & 0.848 & 0.509 & 0.714 \\
\hline Shanxi* & 31 & 1578 & 0.810 & 0.542 & 0.596 & 2412 & 0.882 & 0.593 & 0.531 \\
\hline Bank type & & & & & & & & & \\
\hline $\mathrm{ABC}$ & 47 & 6369 & 0.391 & 0.297 & 0.555 & 11993 & 0.449 & 0.309 & 0.607 \\
\hline RCC & 78 & 3599 & 0.767 & 0.525 & 0.714 & 5920 & 0.849 & 0.525 & 0.730 \\
\hline
\end{tabular}

Note: All means are weighted by the amount of funds.

*In 1998, the share of funds from deposits was 0.87 in Sichuan and 0.92 in Shanxi.

*In 1998, collective firms, private firms, and others accounted for loan shares of 0.69, 0.02, and 0.28 in Sichuan and 0.47, 0.07, and 0.46 in Shanxi. 
Table 2

Financial Intermediation Indicators, 1994 and 1997

\begin{tabular}{lccccc}
\hline & & \multicolumn{2}{c}{1994} & \multicolumn{2}{c}{1997} \\
& $\mathrm{~N}$ & $\begin{array}{c}\text { Loans/ } \\
\text { Inc. }\end{array}$ & $\begin{array}{c}\text { Perf./ } \\
\text { Inc. }\end{array}$ & $\begin{array}{c}\text { Loans/ } \\
\text { Inc. }\end{array}$ & $\begin{array}{c}\text { Perf./ } \\
\text { Inc. }\end{array}$ \\
\hline $\begin{array}{l}\text { Full sample } \\
\text { Income }\end{array}$ & 125 & 0.383 & 0.315 & 0.382 & 0.287 \\
quartiles & & & & & \\
$\quad$ I & 31 & 0.413 & 0.359 & 0.452 & 0.338 \\
II & 32 & 0.318 & 0.258 & 0.316 & 0.265 \\
III & 31 & 0.403 & 0.310 & 0.345 & 0.243 \\
IV & 31 & 0.432 & 0.296 & 0.395 & 0.225 \\
Provinces & & & & & \\
$\quad$ Zhejiang & 30 & 0.488 & 0.430 & 0.498 & 0.397 \\
Jiangsu & 43 & 0.270 & 0.212 & 0.266 & 0.198 \\
Sichuan* & 21 & 0.314 & 0.238 & 0.279 & 0.189 \\
$\quad$ Shanxi* & 31 & 0.605 & 0.431 & 0.561 & 0.339 \\
Bank type & & & & & \\
$\quad$ ABC & 47 & 0.358 & 0.293 & 0.404 & 0.318 \\
RCC & 78 & 0.400 & 0.329 & 0.367 & 0.267 \\
\hline
\end{tabular}

Note: All values are in 1994 yuan, deflated by using provincial consumer price indices. Means for per capita variables are weighted by township population. Means for loans/income and performing loans/income are weighted by total income (income per capita x population).

*In 1998, loans p.c., performing loans p.c., and deposits p.c. were 467, 339, and 870 yuan for Sichuan, and 731, 387, and 1153 yuan for Shanxi. The ratio of loans p.c. to income p.c. and the ratio of performing loans p.c. to income p.c. was 0.27 and 0.19 for Sichuan and 0.50 and 0.27 for Shanxi. 
Table 3

Share of Outstanding Loans that are Nonperforming and Performing, 1994 and 1997

\begin{tabular}{|c|c|c|c|c|c|c|c|c|c|}
\hline & \multirow{3}{*}{$\mathrm{N}$} & \multicolumn{4}{|c|}{1994} & \multicolumn{4}{|c|}{1997} \\
\hline & & \multicolumn{3}{|c|}{ Nonperforming } & \multirow{2}{*}{$\begin{array}{l}\text { Perform } \\
\text {-ing }\end{array}$} & \multicolumn{3}{|c|}{ Nonperforming } & \multirow{2}{*}{$\begin{array}{l}\text { Perform } \\
\text {-ing }\end{array}$} \\
\hline & & Over & Inact. & Dead & & Over & Inact. & Dead & \\
\hline Full sample & 125 & 0.094 & 0.070 & 0.015 & 0.821 & 0.136 & 0.087 & 0.026 & 0.751 \\
\hline $\begin{array}{l}\text { Income } \\
\text { quartiles }\end{array}$ & & & & & & & & & \\
\hline I & 31 & 0.064 & 0.055 & 0.010 & 0.871 & 0.153 & 0.082 & 0.017 & 0.748 \\
\hline II & 32 & 0.108 & 0.073 & 0.006 & 0.813 & 0.076 & 0.055 & 0.028 & 0.840 \\
\hline III & 31 & 0.126 & 0.084 & 0.022 & 0.769 & 0.143 & 0.107 & 0.047 & 0.704 \\
\hline IV & 31 & 0.147 & 0.116 & 0.053 & 0.684 & 0.231 & 0.181 & 0.022 & 0.567 \\
\hline \multicolumn{10}{|l|}{ Provinces } \\
\hline Zhejiang & 30 & 0.084 & 0.031 & 0.004 & 0.881 & 0.133 & 0.060 & 0.009 & 0.797 \\
\hline Jiangsu & 43 & 0.074 & 0.113 & 0.029 & 0.784 & 0.099 & 0.104 & 0.052 & 0.744 \\
\hline Sichuan* & 21 & 0.153 & 0.085 & 0.004 & 0.758 & 0.186 & 0.103 & 0.033 & 0.679 \\
\hline Shanxi* & 31 & 0.139 & 0.114 & 0.034 & 0.713 & 0.209 & 0.157 & 0.031 & 0.604 \\
\hline \multicolumn{10}{|l|}{ Bank type } \\
\hline $\mathrm{ABC}$ & 47 & 0.077 & 0.091 & 0.013 & 0.819 & 0.080 & 0.098 & 0.036 & 0.786 \\
\hline RCC & 78 & 0.104 & 0.057 & 0.016 & 0.822 & 0.177 & 0.078 & 0.019 & 0.726 \\
\hline
\end{tabular}

Note: All means are weighted by the amount of outstanding loans.

Definitions: OvER=overdue loans, INACT=inactive loans (overdue more than 2 years), $\mathrm{DEAD}=$ loans with no expectation of repayment because of the following reasons: a) the borrower has died or cannot be located; b) the borrower has gone bankrupt; or c) the loan is more than three years overdue.

*In 1998, Sichuan and Shanxi overdue loans were 0.28 and 0.48 of outstanding loans. **For Sichuan and Shanxi only. 
Table 4

Loan-Deposit Ratios, 1994 and 1997

\begin{tabular}{lccccc}
\hline & & \multicolumn{2}{c}{1994} & \multicolumn{2}{c}{1997} \\
& & $\begin{array}{c}\text { All } \\
\text { Loans }\end{array}$ & $\begin{array}{c}\text { Perf. } \\
\text { Loans }\end{array}$ & $\begin{array}{c}\text { All } \\
\text { Loans }\end{array}$ & $\begin{array}{c}\text { Perf. } \\
\text { Loans }\end{array}$ \\
\hline $\begin{array}{l}\text { Full sample } \\
\text { Income quartiles }\end{array}$ & 125 & 0.711 & 0.584 & 0.646 & 0.485 \\
I & 31 & 0.706 & 0.615 & 0.632 & 0.472 \\
II & 32 & 0.772 & 0.628 & 0.656 & 0.552 \\
III & 31 & 0.734 & 0.564 & 0.705 & 0.496 \\
IV & 31 & 0.548 & 0.375 & 0.570 & 0.324 \\
Provinces & & & & & \\
Zhejiang & 30 & 0.731 & 0.644 & 0.691 & 0.551 \\
Jiangsu & 43 & 0.715 & 0.561 & 0.577 & 0.429 \\
Sichuan* & 21 & 0.657 & 0.498 & 0.606 & 0.411 \\
Shanxi* & 31 & 0.670 & 0.478 & 0.676 & 0.408 \\
Bank type & & & & & \\
ABC & 47 & 0.758 & 0.621 & 0.686 & 0.539 \\
RCC & 78 & 0.606 & 0.564 & 0.619 & 0.450 \\
\hline Note: All loan & & & & \\
\end{tabular}

Note: All loan values are divided by total deposits. Mean loan-deposit ratios are weighted by the amount of deposits.

*In 1998, Sichuan and Shanxi, loan-deposit ratios were 0.57 and 0.63 , of which performing loans were 0.41 and 0.33 . 
Table 5

Deposits and Income Per Capita, 1994 to 1997

\begin{tabular}{|c|c|c|c|c|c|c|c|c|c|}
\hline & \multirow[b]{2}{*}{$\mathrm{N}$} & \multicolumn{3}{|c|}{1994} & \multicolumn{3}{|c|}{1997} & \multicolumn{2}{|c|}{ Annual \% } \\
\hline & & $\begin{array}{l}\text { Dep. } \\
\text { p.c }\end{array}$ & $\begin{array}{c}\text { Income } \\
\text { p.c. }\end{array}$ & $\mathrm{D} / \mathrm{Y}$ & $\begin{array}{l}\text { Dep. } \\
\text { p.c }\end{array}$ & $\begin{array}{c}\text { Income } \\
\text { p.c. }\end{array}$ & $\mathrm{D} / \mathrm{Y}$ & $\begin{array}{l}\text { Dep. } \\
\text { p.c }\end{array}$ & $\begin{array}{c}\text { Income } \\
\text { p.c. }\end{array}$ \\
\hline Full sample & 125 & 1002 & 1860 & .54 & 1487 & 2515 & .59 & 0.12 & 0.11 \\
\hline Income quartiles & 31 & 1853 & 3169 & 58 & 2801 & 3910 & 72 & 013 & 007 \\
\hline II & 32 & 772 & 1876 & .41 & 1304 & 2709 & .48 & 0.15 & 0.12 \\
\hline III & 31 & 718 & 1308 & .55 & 901 & 1844 & .49 & 0.09 & 0.11 \\
\hline IV & 31 & 590 & 748 & .79 & 771 & 1111 & .69 & 0.08 & 0.13 \\
\hline Provinces & & & & & & & & & \\
\hline Zhejiang & 30 & 1572 & 2357 & .67 & 2377 & 3301 & .72 & 0.12 & 0.11 \\
\hline Jiangsu & 43 & 816 & 2160 & .38 & 1309 & 2844 & .46 & 0.14 & 0.11 \\
\hline Sichuan* & 21 & 593 & 1242 & .47 & 741 & 1612 & .46 & 0.10 & 0.09 \\
\hline Shanxi* & 31 & 785 & 871 & .90 & 998 & 1202 & .83 & 0.08 & 0.11 \\
\hline Bank type & & & & & & & & & \\
\hline $\mathrm{ABC}$ & 47 & 889 & 1882 & .47 & 1488 & 2526 & .59 & 0.15 & 0.11 \\
\hline RCC & 78 & 1076 & 1846 & .58 & 1485 & 2508 & .59 & 0.10 & 0.10 \\
\hline
\end{tabular}

Note: All values are converted to 1994 yuan using provincial CPIs. Means for deposit and loan growth rates are weighted by base year starting values. Mean income p.c. growth is weighted by 1994 township population. 
Table 6

Financial Performance and Level of Economic Development Estimates from OLS Regressions of Performance Indicators on Income Per Capita

\begin{tabular}{|c|c|c|c|c|}
\hline \multirow[t]{2}{*}{ Dependent variable } & \multicolumn{2}{|c|}{$\begin{array}{l}\text { With controls for } \\
\text { provincial differences } \\
\text { (1) }\end{array}$} & \multicolumn{2}{|c|}{$\begin{array}{l}\text { No controls for } \\
\text { provincial differences } \\
\text { (2) }\end{array}$} \\
\hline & 1994 & 1997 & 1994 & 1997 \\
\hline $\begin{array}{l}\text { Performing loans per capita/ } \\
\text { income per capita }\end{array}$ & $* * 0.142$ & $* * * 0.211$ & 0.016 & 0.044 \\
\hline Performing loans/total loans & $* * 0.109$ & $* * * 0.201$ & $* * * 0.150$ & $* * * 0.188$ \\
\hline Loans/deposits & -0.397 & -0.564 & *-0.456 & $* *-0.441$ \\
\hline $\begin{array}{l}\text { Deposits per capita/income per } \\
\text { capita }\end{array}$ & $* * * 1.36$ & $* * * 1.79$ & $* * * 0.911$ & $* * * 1.03$ \\
\hline
\end{tabular}

Notes: $\mathrm{N}=125$, independent variable is log of income per capita (in 1994 yuan).

$* 10$ percent significance level, $* * 5$ percent, $* * * 1$ percent

Specification (1) includes province-bank type interaction dummy variables.

Specification (2) includes dummy variable for bank type only. 
Table 7

Decomposition of Changes in Financial Intermediation (annual growth rates, 1994 to 1997)

\begin{tabular}{|c|c|c|c|c|c|c|c|c|}
\hline & & \multicolumn{4}{|c|}{ Annual growth rates } & \multicolumn{3}{|c|}{ Share of growth } \\
\hline & \multirow[b]{3}{*}{$\mathrm{N}$} & \multirow{2}{*}{$\begin{array}{c}\text { Perf. } \\
\text { loans/ } \\
\text { income } \\
\text { PL/Y }\end{array}$} & \multirow{3}{*}{$\begin{array}{l}\text { Perf. } \\
\text { loan } \\
\text { share } \\
\text { PL/L } \\
2\end{array}$} & \multirow{3}{*}{$\begin{array}{c}\text { Loans/ } \\
\text { Dep } \\
\text { L/D } \\
3\end{array}$} & \multirow{3}{*}{$\begin{array}{c}\text { Dep./ } \\
\text { Income } \\
\text { D/Y } \\
4\end{array}$} & \multirow{3}{*}{$\begin{array}{l}\text { Perf. } \\
\text { loan } \\
\text { share } \\
\text { PL/L } \\
2 / 1 \\
\end{array}$} & \multirow{3}{*}{$\begin{array}{l}\text { Loans/ } \\
\text { dep } \\
\text { L/D } \\
\text { 3/1 }\end{array}$} & \multirow{2}{*}{$\begin{array}{c}\text { Dep./ } \\
\text { Income } \\
. \\
\mathrm{D} / \mathrm{Y}\end{array}$} \\
\hline & & & & & & & & \\
\hline & & 1 & & & & & & \\
\hline Full sample & 125 & -3.10 & -2.97 & -3.20 & 3.10 & 0.97 & 1.04 & -1.01 \\
\hline $\begin{array}{l}\text { Income } \\
\text { quartiles }\end{array}$ & & & & & & & & \\
\hline $\mathrm{I}$ & 31 & -2.01 & -5.07 & -3.69 & 6.77 & 2.54 & 1.85 & -3.39 \\
\hline II & 32 & 0.89 & 1.09 & -5.43 & 5.23 & 1.23 & -6.12 & 5.89 \\
\hline III & 31 & -8.12 & -2.94 & -1.34 & -3.88 & 0.36 & 0.16 & 0.48 \\
\hline IV & 31 & -9.14 & -6.25 & 1.31 & -4.27 & 0.68 & -0.14 & 0.46 \\
\hline \multicolumn{9}{|l|}{ Provinces } \\
\hline Zhejiang & 30 & -2.66 & -3.34 & -1.88 & 2.56 & 1.26 & 0.70 & -0.96 \\
\hline Jiangsu & 43 & -2.28 & -1.75 & -7.15 & 6.58 & 0.76 & 3.09 & -2.85 \\
\hline Sichuan* & 21 & -7.68 & -3.67 & -2.69 & -1.26 & 0.48 & 0.35 & 0.17 \\
\hline Shanxi* & 31 & -8.00 & -5.53 & 0.30 & -2.73 & 0.69 & -0.04 & 0.34 \\
\hline \multicolumn{9}{|l|}{ Bank type } \\
\hline $\mathrm{ABC}$ & 47 & 2.73 & -1.37 & -3.33 & 7.36 & -0.52 & -1.25 & 2.76 \\
\hline RCC & 78 & -6.96 & -4.14 & 0.71 & 0.52 & 1.42 & -0.24 & -0.18 \\
\hline
\end{tabular}

Note: Slight discrepancies between column 1 and the sum of columns 2, 3, and 4 are due to rounding errors. 
Table 8

Governance by Income Quartiles

\begin{tabular}{|c|c|c|c|c|c|c|c|c|}
\hline \multirow[b]{2}{*}{ Variable } & \multicolumn{4}{|c|}{$\begin{array}{l}\text { Governance in } 1997 \\
\text { Income Quartiles }\end{array}$} & \multicolumn{4}{|c|}{$\begin{array}{c}\text { Change in Governance, 1994-1997 } \\
\text { Income Quartiles }\end{array}$} \\
\hline & I & II & III & IV & I & II & III & IV \\
\hline $\begin{array}{l}\text { Loan } \\
\text { Authorization }\end{array}$ & 9.64 & 0.83 & 1.82 & 0.93 & 5.00 & 0.31 & -0.83 & -1.21 \\
\hline Bonus Incentive & 0.56 & 0.48 & 0.47 & 0.63 & NA & NA & -.09 & 0.34 \\
\hline Collateral & 49.6 & 53.1 & 62.3 & 38.7 & 33.2 & 31.1 & 16.1 & 7.2 \\
\hline Gov’t Pressure & 3.71 & 3.58 & 3.88 & 3.45 & 1.2 & 1.1 & 1.5 & 0.28 \\
\hline Rep. Require. & & & & & 0 & -.6 & -.1 & 0 \\
\hline $\begin{array}{l}\text { Time to End } \\
\text { Lawsuit (months) }\end{array}$ & 4.71 & 4.35 & 5.49 & 1.98 & NA & NA & NA & NA \\
\hline Number of Obs & 14 & 24 & 26 & 20 & & & & \\
\hline
\end{tabular}

Notes: Loan authorization limits are reported in 10,000 RMB. Bonus incentives measure the exante bonus in event of target fulfillment as a percentage of the base wage. Collateral is the percentage of loans to TVEs secured with collateral. Government pressure is measured on a decreasing scale from 1-6. 
Table 9

Governance and Non-Performing Loans in Township Branches

\begin{tabular}{|c|c|c|c|c|c|c|c|c|}
\hline \multirow[b]{2}{*}{ Income, 1994} & \multicolumn{4}{|c|}{ Change in Non-Performing Loans } & \multicolumn{4}{|c|}{$\begin{array}{c}\text { Non-Performing } \\
\text { Loans in } 1997 \\
\end{array}$} \\
\hline & $\begin{array}{l}-0.102 \\
(-2.70)\end{array}$ & $\begin{array}{l}-0.128 \\
(-3.28)\end{array}$ & $\begin{array}{l}-0.127 \\
(-3.76)\end{array}$ & $\begin{array}{l}-0.120 \\
(-4.92)\end{array}$ & & & & \\
\hline Income 1997 & & & & & $\begin{array}{l}-0.102 \\
(-5.05\end{array}$ & $\begin{array}{l}-0.111 \\
(-5.82)\end{array}$ & $\begin{array}{l}-0.110 \\
(-5.66)\end{array}$ & $\begin{array}{l}-0.105 \\
(-4.55)\end{array}$ \\
\hline $\begin{array}{l}\text { Loan Authorization, } \\
1994\end{array}$ & & $\begin{array}{l}-0.001 \\
(-0.21)\end{array}$ & $\begin{array}{l}-0.008 \\
(-1.49)\end{array}$ & $\begin{array}{l}-0.014 \\
(-2.39)\end{array}$ & & & & \\
\hline $\begin{array}{l}\text { Loan Authorization, } \\
1997\end{array}$ & & & & & & $\begin{array}{l}-0.001 \\
(-0.41)\end{array}$ & $\begin{array}{l}-0.016 \\
(-1.78)\end{array}$ & $\begin{array}{l}-0.012 \\
(-2.24)\end{array}$ \\
\hline Bonus Incentive, 1997 & & & & & & $\begin{array}{l}-0.080 \\
(-1.46)\end{array}$ & $\begin{array}{l}-0.112 \\
(-2.02)\end{array}$ & $\begin{array}{l}-0.063 \\
(-0.98)\end{array}$ \\
\hline Authorization*Bonus & & & & & & & $\begin{array}{l}0.041 \\
(1.85)\end{array}$ & \\
\hline $\begin{array}{l}\text { Loans w/ Collateral, } \\
1997\end{array}$ & & & & & & $\begin{array}{l}-0.002 \\
(-2.70)\end{array}$ & $\begin{array}{l}-0.002 \\
(-2.57)\end{array}$ & $\begin{array}{l}-0.002 \\
(-2.16)\end{array}$ \\
\hline $\begin{array}{l}\text { Gov’t Intervention, } \\
1994\end{array}$ & & $\begin{array}{l}-0.024 \\
(-1.54)\end{array}$ & $\begin{array}{l}-0.044 \\
(-2.96)\end{array}$ & $\begin{array}{l}-0.040 \\
(-2.85)\end{array}$ & & & & \\
\hline $\begin{array}{l}\text { Gov't Intervention, } \\
1997\end{array}$ & & & & & & $\begin{array}{l}-0.029 \\
(-2.01)\end{array}$ & $\begin{array}{l}-0.032 \\
(-2.16)\end{array}$ & $\begin{array}{l}-0.022 \\
(-1.37)\end{array}$ \\
\hline $\begin{array}{l}\text { Rep. Requirements, } \\
1994\end{array}$ & & & $\begin{array}{l}-0.077 \\
(-2.77)\end{array}$ & $\begin{array}{l}-0.090 \\
(-3.27)\end{array}$ & & & & \\
\hline $\begin{array}{l}\text { Rep. Requirements, } \\
1997\end{array}$ & & & & & & & & $\begin{array}{l}-0.051 \\
(-0.89)\end{array}$ \\
\hline Time to End Lawsuit & & & & & & $\begin{array}{l}0.010 \\
(2.69)\end{array}$ & $\begin{array}{l}0.010 \\
(2.97)\end{array}$ & $\begin{array}{l}0.010 \\
(3.20)\end{array}$ \\
\hline $\begin{array}{l}\text { Non-Performing } \\
\text { Loans, } 1994\end{array}$ & & & & $\begin{array}{l}-0.485 \\
(-3.06)\end{array}$ & & & & \\
\hline Number of Obs. & 59 & 59 & 46 & 46 & & 84 & 84 & 57 \\
\hline $\mathrm{R}^{2}$ & 0.10 & 0.14 & 0.31 & 0.49 & 0.39 & 0.41 & 0.41 & 0.40 \\
\hline
\end{tabular}


Table 10

Changes in Governance between 1994 and 1997

\begin{tabular}{|c|c|c|c|c|c|c|c|c|c|c|}
\hline \multirow{2}{*}{ Income, 1994} & \multicolumn{2}{|c|}{ Loan Authorization } & \multicolumn{2}{|c|}{ Bonus } & \multicolumn{2}{|c|}{ Collateral } & \multicolumn{2}{|c|}{ Gov’t Pressure } & \multicolumn{2}{|c|}{ Rep. Requirements } \\
\hline & $\begin{array}{l}1.633 \\
(1.62)\end{array}$ & $\begin{array}{l}2.300 \\
(1.81\end{array}$ & $\begin{array}{l}-1.014 \\
(-2.57)\end{array}$ & $\begin{array}{l}-1.062 \\
(-3.02\end{array}$ & $\begin{array}{l}10.79 \\
(2.58)\end{array}$ & $\begin{array}{c}5.12 \\
(1.13\end{array}$ & $\begin{array}{l}0.389 \\
(2.45)\end{array}$ & $\begin{array}{l}0.106 \\
(0.84\end{array}$ & $\begin{array}{l}0.028 \\
(1.54)\end{array}$ & $\begin{array}{c}0.074 \\
(1.7)\end{array}$ \\
\hline Loan Authorization, 1994 & & $\begin{array}{l}-0.714 \\
(-7.06\end{array}$ & & & & & & & & \\
\hline Bonus, 1994 & & & & $\begin{array}{l}-0.488 \\
(-1.82)\end{array}$ & & & & & & \\
\hline Loans w/ Collateral, 1994 & & & & & & $\begin{array}{l}-0.377 \\
(-3.71\end{array}$ & & & & \\
\hline Gov’t Pressure, 1994 & & & & & & & & $\begin{array}{l}-0.349 \\
(-4.49)\end{array}$ & & \\
\hline Rep. Requirements, 1994 & & & & & & & & & & $\begin{array}{l}-0.363 \\
(-2.80)\end{array}$ \\
\hline Non-perf. Loans in 1994 & & $\begin{array}{l}2.33 \\
(1.47)\end{array}$ & & $\begin{array}{l}0.844 \\
(1.65)\end{array}$ & & $\begin{array}{l}-25.94 \\
(-1.01)\end{array}$ & & $\begin{array}{l}-1.05 \\
(-1.47)\end{array}$ & & $\begin{array}{l}0.276 \\
(1.36)\end{array}$ \\
\hline Number of observations & 73 & 69 & 25 & 25 & 47 & 45 & 92 & 84 & 94 & 80 \\
\hline $\mathrm{R}^{2}$ & 0.11 & 0.52 & 0.26 & 0.48 & 0.10 & 0.30 & 0.06 & 0.27 & 0.01 & 0.31 \\
\hline
\end{tabular}


Table 11

Financial Indicators, Sichuan and Shanxi, 1997 to 2002

\begin{tabular}{lcccccc}
\hline & 1997 & 1998 & 1999 & 2000 & 2001 & 2002 \\
\hline $\begin{array}{l}\text { Deposits/Assets } \\
\quad \text { Sichuan }\end{array}$ & 0.735 & 0.750 & 0.739 & 0.725 & 0.726 & \\
$\quad$ Shanxi & 0.659 & 0.733 & 0.739 & 0.759 & 0.718 & 0.666 \\
$\quad$ Loans/Liabilities & & & & & & \\
$\quad$ Sichuan & 0.513 & 0.542 & 0.593 & 0.540 & 0.517 & \\
$\quad$ Shanxi & 0.490 & 0.515 & 0.526 & 0.541 & 0.536 & 0.525 \\
$\quad$ Loans/Deposit & & & & & & \\
$\quad$ Sichuan & 0.766 & 0.772 & 0.848 & 0.765 & 0.747 & \\
$\quad$ Shanxi & 0.740 & 0.697 & 0.707 & 0.693 & 0.727 & 0.744 \\
$\quad$ Nonp. loan share & & & & & & \\
$\quad$ Sichuan & 0.484 & 0.544 & 0.605 & 0.685 & 0.512 & \\
$\quad$ Shanxi & 0.482 & 0.408 & 0.750 & 0.670 & 0.581 & 0.441 \\
$\quad$ H-hold loan share & & & & & & \\
$\quad$ Sichuan & 0.681 & 0.725 & 0.719 & 0.700 & 0.732 & \\
$\quad$ Shanxi & 0.546 & 0.554 & 0.558 & 0.569 & 0.590 & 0.620 \\
$\quad$ Enterp. loan share & & & & & & \\
$\quad$ Sichuan & 0.179 & 0.152 & 0.149 & 0.165 & 0.185 & \\
$\quad$ Shanxi & 0.373 & 0.363 & 0.365 & 0.357 & 0.346 & 0.311 \\
\hline
\end{tabular}




\section{Appendix Table 1}

Loan Composition, Sichuan and Shanxi, 1994 and 1998

\begin{tabular}{lccccccccc}
\hline & \multicolumn{1}{c}{1994} & \multicolumn{5}{c}{1998} \\
& $\mathrm{~N}$ & Firms & $\mathrm{HH}$ & $\mathrm{Ag}$ & Other & Firms & $\mathrm{HH}$ & $\mathrm{Ag}$ & Other \\
\hline Full sample & 59 & 0.32 & 0.15 & 0.22 & 0.31 & 0.38 & 0.20 & 0.16 & 0.26 \\
Income quartiles & & & & & & & & & \\
$\quad$ I & 13 & 0.42 & 0.08 & 0.22 & 0.28 & 0.52 & 0.09 & 0.07 & 0.32 \\
$\quad$ II & 14 & 0.33 & 0.04 & 0.36 & 0.27 & 0.29 & 0.16 & 0.29 & 0.27 \\
$\quad$ III & 15 & 0.19 & 0.29 & 0.12 & 0.40 & 0.22 & 0.38 & 0.07 & 0.32 \\
$\quad$ IV & 14 & 0.05 & 0.51 & 0.09 & 0.35 & 0.11 & 0.68 & 0.02 & 0.19 \\
$\quad$ Provinces & & & & & & & & & \\
$\quad$ Sichuan & 23 & 0.48 & 0.09 & 0.19 & 0.24 & 0.50 & 0.18 & 0.16 & 0.17 \\
$\quad$ Shanxi & 36 & 0.19 & 0.20 & 0.25 & 0.36 & 0.24 & 0.27 & 0.11 & 0.38 \\
Bank type & & & & & & & & & \\
$\quad$ ABC & 16 & 0.13 & 0.15 & 0.22 & 0.51 & 0.11 & 0.20 & 0.12 & 0.57 \\
$\quad$ RCC & 43 & 0.45 & 0.15 & 0.22 & 0.18 & 0.48 & 0.24 & 0.14 & 0.15 \\
\hline
\end{tabular}

Note: All means are weighted by the amount of outstanding loans. 